\title{
pH-sensitive polyvinylpyrrolidone-acrylic acid hydrogels: Impact of material parameters on swelling and drug release
}

\author{
Kashif Sohail $^{1}$, Ikram Ullah Khan ${ }^{2,3, *}$,Yasser Shahzad ${ }^{4}$, Talib Hussain ${ }^{4}$, Nazar Muhammad Ranjha \\ ${ }^{1}$ Faculty of Pharmacy, Bahauddin Zakariya University (BZU) Multan, Pakistan, ${ }^{2}$ Laboratory of design and application of \\ bioactive molecules (CAMB), Faculty of Pharmacy University of Strasbourg, France, ${ }^{3}$ College of Pharmacy, Government \\ College (GC) University, Faisalabad, Pakistan, ${ }^{4}$ Division of Pharmacy and Pharmaceutical Science, University of \\ Huddersfield, , Huddersfield, United Kingdom
}

\begin{abstract}
In this study, we fabricated $\mathrm{pH}$-sensitive polyvinylpyrrolidone/acrylic acid (PVP/AA) hydrogels by a free-radical polymerisation method with variation in the content of monomer, polymer and cross-linking agent. Swelling was performed in USP phosphate buffer solutions of $\mathrm{pH} 1.2,5.5,6.5$ and 7.5 with constant ionic strength. Network structure was evaluated by different parameters and FTIR confirmed the formation of cross-linked hydrogels. X-ray crystallography showed molecular dispersion of tramadol $\mathrm{HCl}$. A drug release study was carried out in phosphate buffer solutions of $\mathrm{pH}$ 1.2, 5.5 and 7.5 for selected samples. It was observed that swelling and drug release from hydrogels can be modified by changing composition and degree of cross-linking of the hydrogels under investigation. Swelling coefficient was high at higher $\mathrm{pH}$ values except for the one containing high PVP content. Drug release increased by increasing the $\mathrm{pH}$ of the medium and AA contents in hydrogels while increasing the concentration of cross-linking agent had the opposite effect. Analysis of the drug release mechanism revealed non-Fickian transport of tramadol from the hydrogels.
\end{abstract}

Uniterms: Drugs/release. Hydrogels/pH sensitive. Polyvinylpyrrolidone-acrilic acid/hidrogels. Tramadol hydrochloride. Methylene bisacrylamide.

Nesse estudo, preparamos hidrogéis de polivinilpirrolidona/ácido acrílico(PVP/AA), sensíveis ao $\mathrm{pH}$, por meio de método de polimerização de radical livre, com variações no conteúdo de monômero, de polímero e de agente de ligação cruzada. $\mathrm{O}$ inchamento foi realizado em soluções tampão fosfato USP pH 1,2, 5,5, 6,5 e 7,5, com força iônica constante. A estrutura reticular foi avaliada por diferentes parâmetros e o FTIR confirmou a formação de hidrogéis de ligação cruzada. A cristalografia de raios X mostrou dispersão molecular do cloridrato de tramadol. Realizou-se estudo de liberação do fármaco em soluções tampão fosfato $\mathrm{pH}$ 1,2, 5,5 e 7,5 para amostras selecionadas. Observou-se que o inchamento e a liberação do fármaco dos hidrogéis podem ser modificados mudando-se a composição e o grau de ligação cruzada dos hidrogéis em estudo. O coeficiente de inchamento foi alto em $\mathrm{pH}$ mais altos, exceto para um deles com alto conteúdo de PVP. A liberação do fármaco aumentou com o aumento do pH do meio e do conteúdo em AA nos hidrogéis, enquanto que o aumento na concentração do agente de ligação cruzada apresentou efeito oposto. A análise do mecanismo de liberação do fármaco revelou transporte não Fickiano do tramadol dos hidrogéis.

Unitermos: Fámacos/liberação. Hidrogéis/sensíveis ao pH. Polivinilpirrolidona-ácido acrílico/hidrogéis. Cloridrato de tramadol. Metileno bisacrilamida.

Correspondence: Ikram Ullah Khan. Laboratory of Design and Application of Bioactive Molecules (CAMB), Faculty of Pharmacy, University of Strasbourg, 74 route du Rhin, 67400 Illkirch, France. E-mail: ikramglt@gmail.com 


\section{INTRODUCTION}

Hydrogels are three-dimensional, water-swollen, cross-linked polymeric networks. They are able to retain water due to the presence of hydrophilic functional groups attached to their backbone (Satish et al., 2001; Şahiner et al., 2005; Hussain et al., 2011) while their resistance to dissolution arises from the presence of a chemically or physically cross-linked network (Lin, Metters, 2006). Different physical and chemical properties of hydrogels at the molecular level are used for various applications in biotechnology, tissue engineering and drug delivery due to their hydrophilic character, porous structure and often biocompatible nature (Peppas et al., 2006; Gaharwar et al., 2011). Natural, synthetic or semi-synthetic polymers are used in the preparation of hydrogels (Peppas et al., 2006) and their porosity permits loading of drugs in gel matrix and subsequent release at a predesigned rate in the dissolution media (Entezami, Massoumi, 2006).

Hydrogels have the capacity to reversibly swell or de-swell in water and to maintain the swollen state. They can be deliberately designed to make them responsive to surrounding environmental conditions such as $\mathrm{pH}$, temperature, magnetic fields, antibodies, urea, electric fields, ultrasonic radiation and glucose. These are often referred to as stimuli-responsive or intelligent or smart hydrogels. In the body, they can respond to internal and external stimuli, resulting in significant changes in their swelling, network structure, permeability and mechanical strength (Peppas et al., 2006; Entezami, Massoumi, 2006). Thus change of $\mathrm{pH}$ along the gastrointestinal tract could be a useful tool to formulate targeted drug-delivery systems.

On the basis of network charge, hydrogels are classified as neutral, ionic (cationic or anionic) and amphoteric (both acidic and basic groups). Swelling of ionic hydrogels depends on chemical composition and $\mathrm{pH}$ of the surrounding medium (Lin, Metters, 2006; Ganji, Farahani, 2009). Under suitable conditions, acidic or basic pendant groups are ionised to develop fixed charges, resulting in electrostatic repulsions, solvent penetration and swelling. Anionic hydrogels containing pendant groups such as carboxylic or sulfonic acid swell more at higher $\mathrm{pH}$ (by deprotonation when external $\mathrm{pH}$ is higher than $\mathrm{pK}_{\mathrm{a}}$ of ionisable groups) while at low $\mathrm{pH}$ cationic hydrogels having groups such as amines are ionised to induce swelling of network (Peppas et al., 2000).

Polyvinylpyrrolidone (PVP) has excellent water solubility, absorbency and biocompatibility. Hydrogels of PVP have limited applications because of its inferior mechanical properties. To increase its mechanical properties, PVP and its monomer, $N$-vinyl pyrrolidone, have been copolymerised with acrylic acid, methacrylates and other vinyl monomers (Zhao et al., 2006; Mishra et al., 2008). Furthermore, desired mechanical properties could be achieved by selecting a suitable cross-linking agent, degree of cross-linking and monomeric composition (Anseth et al., 1996; Devine, Higginbotham, 2005; Jin et al., 2009). Acrylic acid (AA) is a $\mathrm{pH}$ and electrically sensitive material. It forms complexes with polybases (Ray et al., 2008). PVP and AA have applications in $\mathrm{pH}$-controlled drug delivery, ocular drug formulations, synthesis of muco-adhesive microspheres and fabrication of polymerceramic composites (Kadłubowski et al., 2007). So far, Devine (Devine, Higginbotham, 2005), Hafeez (Hafeez et al., 2005), Kadlubowski (Kadłubowski et al., 2007) and Bajpai (Bajpai et al., 2005) have prepared PVP/AA hydrogels and addressed different issues including gel strength, immobilisation of $\mathrm{TiO}_{2}$ nanoparticles, chemical sensor properties and comparison of vitamin B12 release behaviour through traditional dissolution apparatus and flow-through diffusion cells, respectively.

These studies never combined detailed analysis of network parameters necessary for the final application, different factors affecting swelling, drug release and finally nature of drug after encapsulation and analysis of release pattern. Therefore, this work focused on synthesising $\mathrm{pH}$-sensitive PVP/AA hydrogels by freeradical polymerisation for colon targeting. Different formulations with variation in the content of polymer, monomer and degree of cross-linking were evaluated in terms of swelling and drug release and attempts were made to correlate these with the network parameters. Finally, the state of the encapsulated drug and release behaviour of a model hydrophilic drug was evaluated in optimum formulations.

\section{MATERIAL AND METHODS}

\section{Material}

The monomer used was acrylic acid (Merck, Germany) and the polymer was poly ( $N$-vinyl-2pyrrolidone) (Mw 40,000; Biomedicals, France). N,Nmethylene bisacrylamide (Merck, Germany) was used as a cross-linking agent. Benzyl peroxide (Merck, Germany) was used as initiator. Potassium bromide was purchased from Merck, Germany, for IR spectroscopy. All other chemicals used were of analytical grade.

\section{Synthesis of PVP/AA hydrogels}

We synthesised a series of cross-linked hydrogels 
TABLE I - Formulation of PVP/AA hydrogels*

\begin{tabular}{lccccc}
\hline Sample code & PVP/100g solution & $\begin{array}{c}\text { Acrylic Acid/100 } \\
\text { solution }\end{array}$ & PVP/AA (Wt \%) & $\begin{array}{c}\text { Methylene } \\
\text { bisacrylamide }(\mathrm{g})\end{array}$ & $\begin{array}{c}\text { Methylene bisacrylamide } \\
\text { /100 g of AA }\end{array}$ \\
\hline $\mathrm{A}_{1}$ & 13.32 & 44.40 & $23.08 / 76.92$ & 0.133 & 0.3 \\
$\mathrm{~A}_{2}$ & 13.32 & 53.28 & $20 / 80$ & 0.159 & 0.3 \\
$\mathrm{~A}_{3}$ & 13.32 & 62.16 & $17.65 / 82.35$ & 0.186 & 0.3 \\
$\mathrm{~B}_{1}$ & 6.66 & 48.84 & $12 / 88$ & 0.146 & 0.3 \\
$\mathrm{~B}_{2}$ & 11.10 & 48.84 & $18.52 / 81.48$ & 0.146 & 0.3 \\
$\mathrm{~B}_{3}$ & 17.76 & 48.84 & $26.66 / 73.34$ & 0.146 & 0.3 \\
$\mathrm{C}_{1}$ & 13.32 & 53.28 & $20 / 80$ & 0.106 & 0.2 \\
$\mathrm{C}_{2}$ & 13.32 & 53.28 & $20 / 80$ & 0.213 & 0.4 \\
$\mathrm{C}_{3}$ & 13.32 & 53.28 & $20 / 80$ & 0.266 & 0.5 \\
\hline
\end{tabular}

*Benzyl peroxide was used as initiator at a concentration of $1 \mathrm{wt} \%$ of AA. Ethanol was used as solvent to dissolve all the components.

of PVP/AA by a previously reported method (Ranjha et al., 2010). Briefly, weighed quantities of ingredients were dissolved in ethanol and poured into polyethylene tubes. After nitrogen bubbling for 15-20 minutes, capped tubes were placed in a water bath. The temperature was gradually increased from $45^{\circ} \mathrm{C}$ to $65^{\circ} \mathrm{C}$ to avoid autoacceleration and bubble formation. The heating scheme was $45^{\circ} \mathrm{C}$ for $1 \mathrm{~h}, 50^{\circ} \mathrm{C}$ for $2 \mathrm{~h}, 55^{\circ} \mathrm{C}$ for $3 \mathrm{~h}, 60^{\circ} \mathrm{C}$ for $4 \mathrm{~h}, 65^{\circ} \mathrm{C}$ for $12 \mathrm{~h}$. After cooling, cylinders were removed from the tubes and cut into $6 \mathrm{~mm}$ length discs. These discs were washed with ethanol water $(50: 50, \mathrm{v} / \mathrm{v})$ for 1 week to remove un-reacted monomers. These discs were initially dried at room temperature followed by drying in an oven at $40-45^{\circ} \mathrm{C}$ to achieve a constant weight. Afterwards these discs were stored in desiccators until further use. Compositions of various formulations are given in Table I and their possible structure is shown in Figure 1.

\section{Characterization of PVP/AA hydrogels}

\section{Swelling coefficient}

Dynamic and equilibrium swelling coefficients of cross-linked hydrogels were determined in $0.05 \mathrm{M}$ USP phosphate buffer solutions of $\mathrm{pH} 1.2,5.5,6.5$ and 7.5 , while ionic strength was adjusted to 0.11 by adding the calculated amount of $\mathrm{NaCl}$.

The swelling coefficient of each sample was calculated from the following equation (Peppas, 1986):

$$
q=\frac{W_{t}}{W_{d}}
$$

where $\mathrm{W}_{\mathrm{t}}$ is weight of swollen gel at time $\mathrm{t}$, and $\mathrm{W}_{\mathrm{d}}$ is the initial weight of dry gel.

For equilibrium swelling, all the samples were

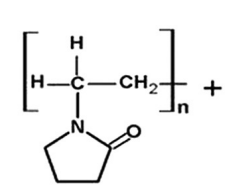

Polyvinyl pyrrolidone

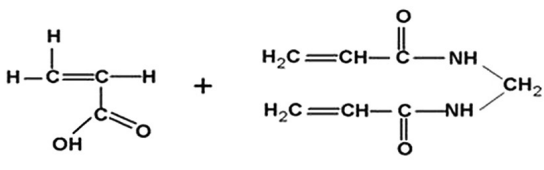

Acrylic acid

$N, N$-methylene bisacrylamide

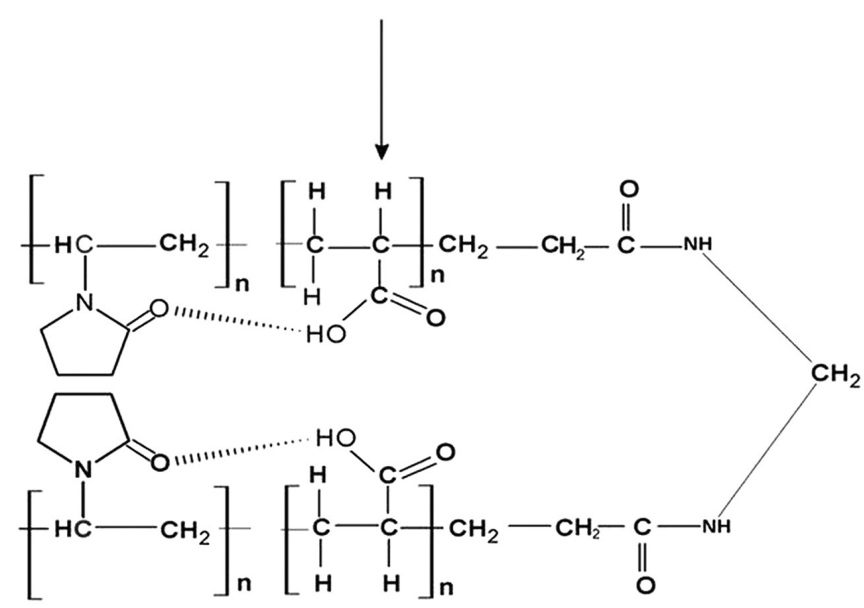

FIGURE 1 - Possible structure of polyvinylpyrrolidone/acrylic acid hydrogel.

retained in the same container until they attained a constant weight (Koç et al., 2008).

\section{Drug loading}

Six selected samples were soaked in $1 \% \mathrm{w} / \mathrm{v}$ solution of tramadol $\mathrm{HCl}$ in an ethanol water mixture $(50: 50, \mathrm{v} / \mathrm{v})$ until equilibrium. Drug-loaded discs were dried at room temperature and then dried in an oven at $40-45^{\circ} \mathrm{C}$ until constant weight was achieved.

For determining percentage drug loading, weighed quantitities of the samples were extracted repeatedly using 
ethanol/water solution (50:50, v/v) up to exhaustion and then concentration of the drug in the pooled extract was determined spectrophotometrically at a wavelength of $271 \mathrm{~nm}$. Percentage drug loading was calculated by the following equation (Szepes et al., 2008):

$$
\text { Drug Loading } \%=\frac{W_{D}-W_{d}}{W_{d}} \times 100
$$

where $\mathrm{W}_{\mathrm{d}}$ is the dry weight of disc before loading and $\mathrm{W}_{\mathrm{D}}$ is dry weight of loaded gels.

\section{Structural analysis of PVP/AA hydrogels}

Use of hydrogels for drug delivery purposes largely depends on gel performance, which in turn is dependent on their bulk structure. The network structures of hydrogels were determined by using following parameters.

\section{Diffusion coefficient (D)}

Diffusion coefficient is the rate at which the diffusing substance is transported between opposite faces of a unit cube system and depends on polymer segmental mobility. It was determined by the following equation (Crank, 1979):

$$
D=\pi\left(\frac{h \cdot \theta}{4 . q_{e q}}\right)^{2}
$$

where $\mathrm{q}_{\mathrm{eq}}$ is swelling of gel at equilibrium, $\theta$ is the slope of the linear part of the swelling curves and $h$ is the initial thickness of gel before swelling.

\section{Determination of average molecular weight between cross-links $\left(M_{c}\right)$}

Average molecular weight between two adjacent cross-links represents the degree of cross-linking of hydrogel networks and describes the mixing of polymer and liquid. The Flory-Rhener equation can be used to determine $\mathrm{M}_{\mathrm{c}}$ (Flory, 1953):

$$
M_{c}=\frac{d_{p} V_{s}\left(V_{2, s}^{1 / 3}-V_{2, s} / 2\right)}{\ln \left(1-V_{2, s}\right)+V_{2, s}+\chi V_{2, s}^{2}}
$$

where $d_{p}$ and $d_{s}(1.0 \mathrm{~g} / \mathrm{mL})$ are the densities of the polymer and solvent respectively. $\mathrm{V}_{\mathrm{s}}$ is the molar volume of the solvent $(18 \mathrm{~mL} / \mathrm{mol})$ and $\chi$ is the Flory polymer-solvent interaction parameter. $\mathrm{V}_{2 \mathrm{~s}}$ is the volume fraction of polymer in the swollen state. $\mathrm{V}_{2, \mathrm{~s}}, \chi$ are calculated from the following equations, respectively:

$$
V_{2 s}=\left[1+\frac{d_{p}}{d_{s}}\left(\frac{M_{a}}{M_{b}}-1\right)\right]^{-1}
$$

where $d_{p}$ and $d_{s}$ are the densities of the polymer and solvent $\mathrm{M}_{\mathrm{b}}$ and $\mathrm{M}_{\mathrm{a}}$ are the masses of the dry and swollen polymers respectively (Lin, Metters, 2006).

$$
\chi=\frac{\ln \left(1-V_{2, s}\right)+V_{2, s}}{V_{2, s}^{2}}
$$

where $\mathrm{V}_{2, \mathrm{~s}}$ is the volume fraction of the swollen gel in the swollen state (Crank, 1979).

Determination of number of links between crosslinks $(N)$

The number of links between two cross-links ' $N$ ' can be calculated from the value of the average molecular weight between cross-links as follows (Peppas et al., 2006; Peppas et al., 2000):

$$
N=\frac{2 M_{c}}{M_{r}}
$$

where $M_{c}$ is the average molecular weight between crosslinks and $\mathrm{M}_{\mathrm{r}}$ is the molar mass of the repeating unit and was calculated by the following equation:

$$
M_{r}=\frac{m_{P V P} M_{P V P}+m_{A A} M_{A A}+m_{M B A} M_{M B A}}{m_{P V P}+m_{A A}+m_{M B A}}
$$

where $\mathrm{m}_{\mathrm{AA}}, \mathrm{m}_{\mathrm{PVP}}$, and $\mathrm{m}_{\mathrm{MBA}}$ are the masses of AA, PVP and MBA, respectively. $\mathrm{M}_{\mathrm{AA}}, \mathrm{M}_{\mathrm{PVP}}$, and $\mathrm{M}_{\mathrm{MBA}}$ are the molar masses of AA, PVP and MBA.

\section{Sol-gel analysis}

Non-washed samples were subjected to Sohxlet extraction for $4 \mathrm{~h}$ with deionised water. After drying, the gel fraction was calculated by using the initial weight of dry gel $\left(\mathrm{W}_{0}\right)$ and the weight of extracted dry gel $\left(\mathrm{W}_{1}\right)$ according to the following equations (Sen, Avcl, 2005):

$$
\operatorname{Solfraction}(\%)=\frac{\left(W_{\mathrm{O}}-W_{1}\right)}{W_{\mathrm{O}}} \times 100
$$




$$
\text { Gel fraction }(\%)=100-\text { Sol fraction }
$$

\section{Porosity measurement}

The solvent replacement method was adopted to determine porosity. Dried hydrogels were immersed in absolute ethanol overnight and weighed after blotting excess ethanol from the surface. The porosity was calculated by following equation ( $\mathrm{Lin}, \mathrm{Lu}, 2002$ ):

$$
\text { Porosity }=\frac{\left(M_{2}-M_{1}\right)}{\rho V} \times 100
$$

where $M_{1}$ and $M_{2}$ are the masses of hydrogel before and after immersion in ethanol, respectively, $\rho$ is the density of absolute ethanol and $\mathrm{V}$ is the volume of hydrogel.

\section{Fourier transform infrared (FTIR) spectroscopic analysis}

Polymerisation (Khan et al., 2013) of cross-linked samples was monitored by the potassium bromide pellet method. All the spectra were recorded between 4000 and $400 \mathrm{~cm}^{-1}$ using a FTIR spectrometer (FTIR $8400 \mathrm{~S}$, Shimadzu).

\section{X-ray diffraction (XRD)}

XRD spectra of drug-loaded and unloaded hydrogels were recorded using Bruker D8 Discover apparatus (Germany). Eva software was used for the data processing (Evaluation Package Bruker, Germany). Patterns were obtained at a scan speed of $4^{\circ} /$ minute with $2 \theta$ between $8^{\circ}$ and $70^{\circ}$.

\section{Drug release}

Dissolution studies were performed in $500 \mathrm{~mL}$ of freshly prepared $0.05 \mathrm{M}$ phosphate buffer solutions having $\mathrm{pH}$ of 1.2, 5.5 and 7.5 using USP paddle apparatus at $100 \mathrm{rpm}$ for $12 \mathrm{~h}$. Temperature of dissolution medium was maintained at $37^{\circ} \mathrm{C}$. For each sample, $5 \mathrm{~mL}$ of media was withdrawn at a predetermined time and replaced with the same volume of fresh medium to maintain constant volume. Samples were assayed for tramadol $\mathrm{HCl}$ release at $271 \mathrm{~nm}$ (IRMECO U.V. Vis. Spectrophotometer model U2020). Percentage drug release was calculated from a standard calibration curve. Each experiment was performed in triplicate and the mean is reported $(n=3)$.

\section{Analysis of drug release pattern}

Korsmeyer-Peppas equation was used for tramadol $\mathrm{HCl}$ modelling.

$$
\text { Peppas model } \quad \mathrm{M}_{\mathrm{t}} / \mathrm{M}_{\infty}=\mathrm{K} \mathrm{t}^{\mathrm{n}}
$$

where $M_{t} / M_{\infty}$ is the fraction of drug released at time " $t$ ", $\mathrm{K}$ is a constant incorporating the structural and geometric characteristics of the gels and " $n$ " is the release exponent or diffusional exponent. When $n=0.5$, order of release is Fickian, $\mathrm{n}=1$ responds to a case II transport, while $0.5<\mathrm{n}<1$ corresponds to a diffusion mechanism that is non-Fickian (Ranjha et al., 2009).

\section{RESULTS AND DISCUSSION}

\section{Effect of variation of $\mathrm{pH}$, monomer, polymer and cross-linker on swelling behaviour}

Swelling behaviour of hydrogels plays an important role in controlled drug release behaviour. Therefore, it was important to investigate various factors affecting the swelling. The nature of $\mathrm{pH}$-sensitive hydrogels strongly depends on $\mathrm{pH}$ of the medium. To study this effect, dried hydrogels were immersed in $0.05 \mathrm{M}$ phosphate buffer solution of varying $\mathrm{pH}$. Effect of $\mathrm{pH}$ on dynamic and equilibrium swelling of various samples containing different contents of AA, PVP and MBA are given in Table II. From these results, it is obvious that there is a significant variation in the degree of swelling at different $\mathrm{pH}$ values. These hydrogels show low swelling at acidic $\mathrm{pH}$, while the degree of swelling increases as the $\mathrm{pH}$ of medium increases.

After confirming the swelling effect at low and high $\mathrm{pH}$, we were further interested to see the swelling as a function of monomeric composition, polymer concentration, and cross-linker concentration. As can be seen in Table II, dynamic swelling increases as a function of $\mathrm{pH}$ of the swelling medium by increasing the concentration of AA content in the hydrogels. Dynamic and equilibrium swelling coefficients do not increase substantially at low $\mathrm{pH}$ but, at higher $\mathrm{pH}$, there is a significant increase in the swelling coefficient with increasing AA concentration (Table II) due to availability of more carboxyl groups for ionisation. As a result, electrostatic repulsion increases along the chain, which causes an expansion of the chain. Similar results were reported by Jin et al. (2009), who prepared poly( $N$-vinylpyrrolidone) and poly(acrylic acid) semi-interpenetrating polymer network hydrogels and observed an increase in swelling by increasing the amount of acrylic acid in the hydrogels. 
TABLE II - Dynamic and equilibrium swelling coefficients of PVP/AA hydrogels using MBA as cross-linking agent

\begin{tabular}{|c|c|c|c|c|c|c|c|c|}
\hline \multirow{2}{*}{$\begin{array}{l}\text { Sample } \\
\text { code }\end{array}$} & \multicolumn{4}{|c|}{ Dynamic swelling coefficient $(8 \mathrm{~h})$} & \multicolumn{4}{|c|}{ Equilibrium swelling coefficient } \\
\hline & $\mathrm{pH} 1.2$ & $\mathrm{pH} 5.5$ & $\mathrm{pH} 6.5$ & $\mathrm{pH} 7.5$ & $\mathrm{pH} 1.2$ & $\mathrm{pH} 5.5$ & $\mathrm{pH} 6.5$ & $\mathrm{pH} 7.5$ \\
\hline$A_{1}$ & 1.112 & 1.495 & 3.627 & 5.905 & 1.261 & 2.206 & $\mathrm{a}$ & $\mathrm{a}$ \\
\hline $\mathrm{A}_{2}$ & 1.144 & 1.84 & 4.225 & 6.183 & 1.373 & 2.863 & $\mathrm{a}$ & a \\
\hline $\mathrm{A}_{3}$ & 1.224 & 1.925 & 4.927 & 6.981 & 2.851 & 4.273 & 19.260 & a \\
\hline $\mathrm{B}_{1}$ & 1.098 & 1.765 & 3.514 & 6.393 & 1.248 & 4.339 & 20.794 & a \\
\hline $\mathrm{B}_{2}$ & 1.115 & 1.354 & 3.368 & 5.507 & 1.286 & 2.010 & $\mathrm{a}$ & a \\
\hline $\mathrm{B}_{3}$ & 1.125 & 1.211 & 2.715 & 4.435 & 1.335 & 1.247 & $\mathrm{a}$ & $\mathrm{a}$ \\
\hline $\mathrm{C}_{1}$ & 1.801 & 2.59 & 4.159 & 9.40 & 3.241 & 6.175 & $\mathrm{a}$ & $\mathrm{a}$ \\
\hline $\mathrm{C}_{2}$ & 1.088 & 1.159 & 3.164 & 4.212 & 1.232 & 2.783 & $\mathrm{a}$ & $\mathrm{a}$ \\
\hline $\mathrm{C}_{3}$ & 1.078 & 1.114 & 2.41 & 3.139 & 1.194 & 2.648 & 14.910 & $\mathrm{a}$ \\
\hline
\end{tabular}

"a" stands for samples broke

In order to investigate the influence of PVP content on swelling behaviour, we observed their swelling performance at various $\mathrm{pH}$. Table II shows the effect of PVP concentration on equilibrium and dynamic swelling of these hydrogels. Results showed that both dynamic and equilibrium swelling coefficients increased with increasing $\mathrm{pH}$ but the reverse was true with increasing PVP content. Low swelling coefficients at low $\mathrm{pH}$ is due to a high content of carboxylic acid groups that remain un-ionised at this $\mathrm{pH}$. As the $\mathrm{pH}$ increases, swelling also increases due to ionisation of carboxylic groups. However, it is interesting to see that swelling coefficients of formulations with various concentration of PVP at higher $\mathrm{pH}$ decrease with increasing content of PVP, which may be due to a decrease in $w t \%$ of AA in formulations. As the PVP content increases, the number of carboxylate groups decreases, resulting in a decrease in the intermolecular repulsion forces, which leads to reduction of free spaces available for swelling. Secondly, PVP hydrogels swell by absorption of water, which is kept in the free volume of cross-linked polymer, as the PVP contents are increased it also decreases the free volume resulting in decreased swelling at the same $\mathrm{pH}$ (El-Hag et al., 2003; Benamer et al., 2006). Benamer et al. (2006) reported that by increasing the concentration of PVP in hydrogels, equilibrium swelling decreases. Finally, we observed the effect of cross-linker on the degree of hydrogel swelling. The effect of the degree of cross-linking on the dynamic and equilibrium swelling was carried out while keeping the PVP and AA contents constant. It was observed that swelling decreases with increasing concentrations of cross-linker (Table II) due to the increase in the degree of cross-linking between polymer chains, which prevents their expansion.

\section{Structural parameters of PVP/AA hydrogels}

The most important parameters to characterise the hydrogel network are $\mathrm{M}_{\mathrm{c}}$ and $\mathrm{V}_{2, \mathrm{~s}}$. Our results shows values of $\mathrm{V}_{2, \mathrm{~s}}$ and $\chi$ decreased with increasing concentration of AA and were increased by increasing concentration of PVP and cross-linking agent. $M_{c}$ and $\mathrm{N}$ are directly proportional to concentration of AA and inversely proportional to concentration of PVP and crosslinker. Values of D increased with higher concentration of AA and decreased with cross-linker and PVP (Table III). As far as $\mathrm{V}_{2, \mathrm{~s}}$ is concerned, Katime et al. (2001) reported similar findings and suggested that the value of $\mathrm{V}_{2, \mathrm{~s}}$ is high for hydrogels containing no itaconic acid (IA) because of low water absorption. Inverse proportionality of $M_{c}$ to cross-linker is explained by the fact that $M_{c}$ is related to cross-linked density: if cross-linked density is higher, $M_{c}$ will be lower. By increasing the concentration of cross-linker, cross-linked density increases and the value of $M_{c}$ decreases. Similar results were published by Benamer et al. (2006) who prepared PVP hydrogels that were cross-linked by using a gamma-irradiation technique. These parameters show that gel swelling can be tuned by increasing concentration of AA while using an optimum concentration of cross-linker and polymer content.

\section{Sol-Gel Fraction}

Table III shows the effects of AA, PVP and crosslinking agent concentrations on the gel fraction of different formulations of PVP/AA. It was observed that by increasing the concentration of $\mathrm{AA}\left(\mathrm{A}_{1}\right.$ to $\left.\mathrm{A}_{3}\right), \operatorname{PVP}\left(\mathrm{B}_{1}\right.$ to $\left.B_{3}\right)$ and $\operatorname{MBA}\left(C_{1}\right.$ to $\left.C_{3}\right)$. The gel fraction tends to increase 
TABLE III - Structural parameters and diffusion coefficient of PVP/AA hydrogels

\begin{tabular}{lcccccccc}
\hline Sample code & $\mathrm{V}_{2 \mathrm{~s}}$ & $\mathrm{X}$ & $\mathrm{M}_{\mathrm{c}}$ & $\mathrm{M}_{\mathrm{r}}$ & $\mathrm{N}$ & $\begin{array}{c}\mathrm{D} \times 10^{-5} \\
\left(\mathrm{~cm}^{2} \mathrm{sec}^{-1}\right)\end{array}$ & $\begin{array}{c}\text { Porosity (\%) } \\
(\%)\end{array}$ & $\begin{array}{c}\text { Gel fraction } \\
(\%)\end{array}$ \\
\hline $\mathrm{A}_{1}$ & 0.2418 & 0.5987 & 879.62 & 81.24 & 21.65 & 7.97 & 14.88 & 91.94 \\
$\mathrm{~A}_{2}$ & 0.2054 & 0.5811 & 2402.22 & 80.05 & 60.01 & 9.19 & 18.33 & 92.54 \\
$\mathrm{~A}_{3}$ & 0.1890 & 0.5736 & 2957.68 & 79.14 & 74.74 & 9.57 & 21.35 & 93.20 \\
$\mathrm{~B}_{1}$ & 0.2274 & 0.5916 & 1241.62 & 76.95 & 32.26 & 6.08 & 15.84 & 86.15 \\
$\mathrm{~B}_{2}$ & 0.3492 & 0.6590 & 759.54 & 79.47 & 19.11 & 5.58 & 22.32 & 90.18 \\
$\mathrm{~B}_{3}$ & 0.4931 & 0.7665 & 634.13 & 82.63 & 15.34 & 5.23 & 33.95 & 92.28 \\
$\mathrm{C}_{1}$ & 0.1106 & 0.5402 & 3922.6 & 79.99 & 98.07 & 5.02 & 26.95 & 92.10 \\
$\mathrm{C}_{2}$ & 0.2312 & 0.5935 & 1218.65 & 80.11 & 30.42 & 0.42 & 15.85 & 92.79 \\
$\mathrm{C}_{3}$ & 0.2317 & 0.5937 & 1121.17 & 80.17 & 27.96 & 0.25 & 11.21 & 92.98 \\
\hline
\end{tabular}

$\mathbf{V}_{2 s}$ : volume fraction of polymer at equilibrium swelling in USP phosphate buffer solution, $\chi$ : solvent interaction parameter, $\mathbf{M}_{\mathbf{c}}$ : average value of molecular weight between crosslinks, $\mathbf{M}_{\mathbf{r}}$ : molar mass of the repeating unit, $\mathbf{N}$ : number of links between two crosslinks, D: diffusion coefficient at $\mathrm{pH} 5.5$

while the sol fraction decreases. Sen et al. (2005) prepared hydrogels of PVP and carrageenan that showed increased gel fraction by increasing PVP. As the concentration of cross-linking agent increases, there will be more crosslinking and, in consequence, the gel fraction increases. Yin et al. (2007) prepared poly(acrylic acid-co-acrylamide)/Ocarboxymethyl chitosan hydrogels and reported that the gel fraction increased with increasing concentration of polymer, monomer and cross-linker.

\section{Porosity}

Table III shows the porosity of different formulations of PVP/AA. It is evident that by increasing AA and PVP contents, porosity increases. By increasing the concentration of polymer and monomer, the viscosity of the solution increases, which prevents escape of the bubbles and results in formation of interconnected channels. It was further observed that PVP forms larger pores than AA due to its higher molecular weight and polymer chain length. Porosity is decreased by increasing the concentration of MBA $\left(\mathrm{C}_{1}\right.$ to $\left.\mathrm{C}_{3}\right)$ because it augments cross-linking density and reduces mesh size of hydrogels. Ranjha et al. (2011) found that porosity is increased by increasing pectin and AA in gels while it is reduced with increased concentration of cross-linker.

\section{Fourier transform infrared (FTIR) spectroscopy}

In order to confirm the network structure of prepared gels, FTIR studies were used. It is a sensitive technique to detect the shift in the position of bonds, which confirms the interaction. The main peaks of AA are $-\mathrm{OH}$ stretch at
$3380 \mathrm{~cm}^{-1}$, $-\mathrm{CH}$ stretch at $2922 \mathrm{~cm}^{-1}$ and $-\mathrm{C}=\mathrm{O}$ stretch at $1718.5 \mathrm{~cm}^{-1}$ (Ranjha et al., 2011).

PVP shows peaks at $2924 \mathrm{~cm}^{-1}$ for $\mathrm{CH}$ stretching, a stretching peak between 1650 to $1659 \mathrm{~cm}^{-1}$ for carbonyl stretching $(\mathrm{C}=\mathrm{O})$ and $1290 \mathrm{~cm}^{-1}$ for amide band III $(\mathrm{C}-\mathrm{N}$ stretch) (Jin et al., 2006). In the FTIR spectrum (Figure 2 ), carbonyl bands in complex were broader than in pure PVP and AA, and are evidence of intermolecular hydrogen bonding. N-H stretching between 3330 and $3060 \mathrm{~cm}^{-1}$ and C-N stretching at $1650 \mathrm{~cm}^{-1}$ indicates the presence of cross-linking agent (MBA).

\section{X-ray diffraction}

Every crystalline drug has a well-defined crystalline pattern that can be observed by XRD analysis and can be used as a tool for their identification (Khan et al., 2013). As per guidance of international committee on diffraction data (ICDD) about analysis of drugs, major compounds should be 5\% weight in formulation. Sensitivity can be further improved $(<0.5 \% \mathrm{wt})$ by long data collection times, employing high-resolution optics or an intense $\mathrm{X}$-ray source such as a synchrotron or powerful detectors. We carried out XRD analysis on tramadol, and drugloaded and unloaded hydrogels. Tramadol shows typical crystalline peaks at $10^{\circ}, 12^{\circ}, 16^{\circ}, 18^{\circ}, 24^{\circ}, 24^{\circ}$ and $26^{\circ}$ (Figure 3). These diffraction peaks are not observed in drug-loaded hydrogels indicating an amorphous nature.

\section{Influence of different parameters on drug loading and release behaviour}

To investigate drug-release properties, we chose 


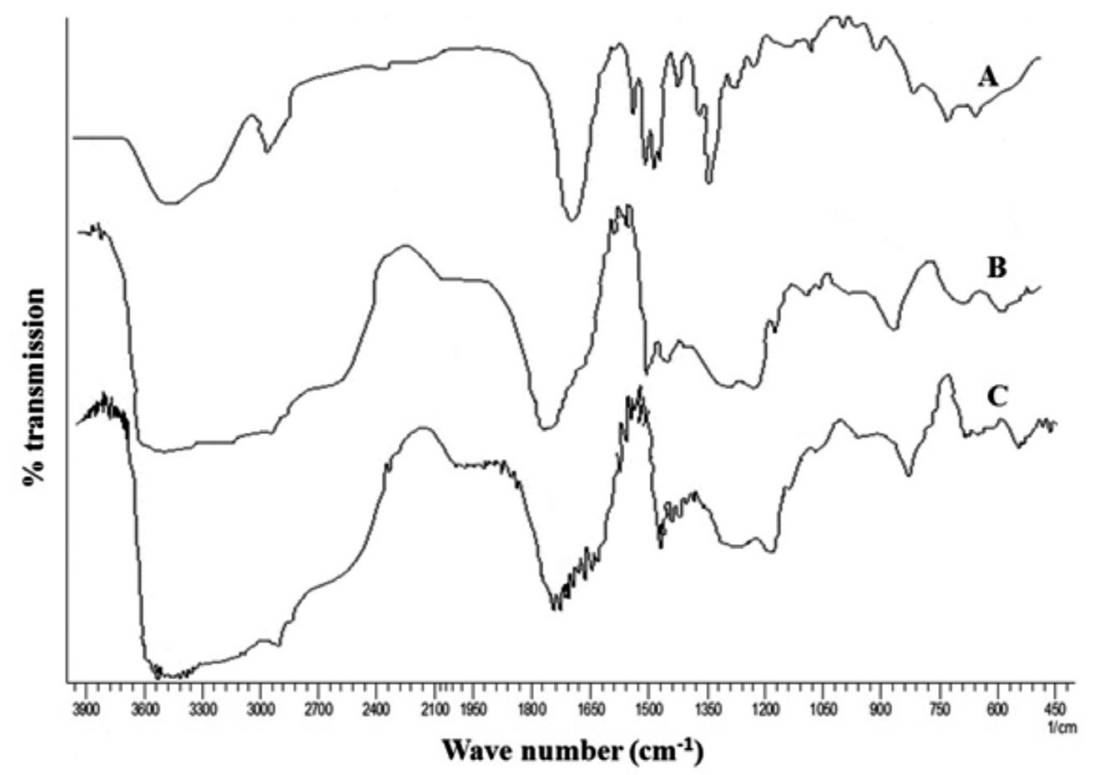

FIGURE 2 - FTIR spectra (A) PVP (B) acrylic acid (C) PVP/AA hydrogel (12:88).

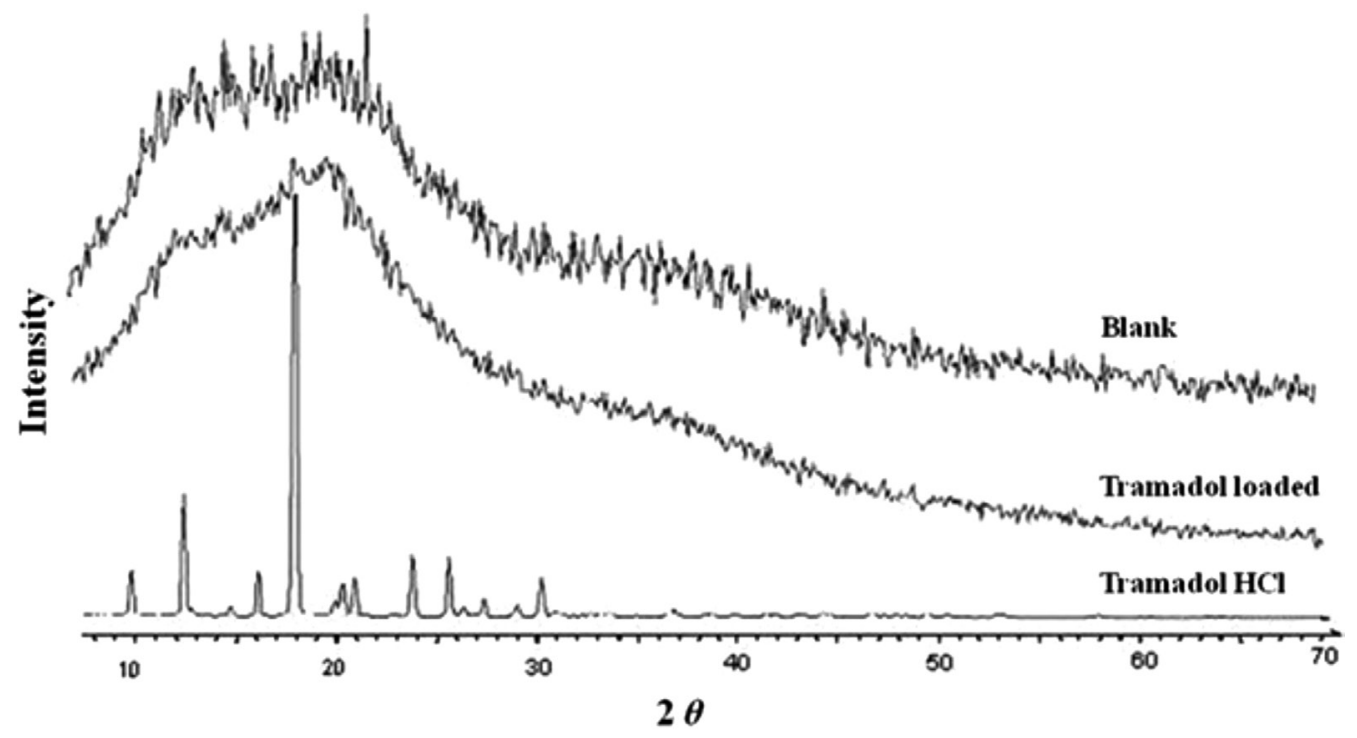

FIGURE 3 - XRD of PVP/AA hydrogel (Blank), drug-loaded PVP/AA hydrogel and tramadol HCl.

tramadol $\mathrm{HCl}$ as a model hydrophilic drug. Only those samples showing significant swelling were selected for drug release studies while others showing poor swelling were rejected $\left(\mathrm{B}_{1}, \mathrm{~B}_{2}, \mathrm{~B}_{3}\right)$. Table IV shows the amount of tramadol $\mathrm{HCl}$ loaded in the various samples. Drug loading is increased by increasing acrylic acid content (a) and decreased by an increase of cross-linker content at constant PVP/AA ratio (b). Point "a" can be explained by looking at Table III where there is an increase in porosity of formulations with higher acrylic acid content, which could lead to accommodation of higher drug contents. Another possible reason is the interaction between drug and carboxylic groups in polymer chains. In the literature,
TABLE IV - Amount of tramadol HCl loaded in different formulation of PVP/AA hydrogels

\begin{tabular}{lcc}
\hline \multirow{2}{*}{$\begin{array}{l}\text { Sample } \\
\text { code }\end{array}$} & \multicolumn{2}{c}{ Amount of tramadol $\mathrm{HCl}$ loaded $(\mathrm{g} / \mathrm{g}$ of dry gel $)$} \\
\cline { 2 - 3 } & By swelling & By extraction \\
\hline $\mathrm{A}_{1}$ & 0.0127 & 0.0121 \\
$\mathrm{~A}_{2}$ & 0.0196 & 0.0184 \\
$\mathrm{~A}_{3}$ & 0.0353 & 0.0337 \\
$\mathrm{C}_{1}$ & 0.0407 & 0.0387 \\
$\mathrm{C}_{2}$ & 0.0133 & 0.0129 \\
$\mathrm{C}_{3}$ & 0.0106 & 0.0113 \\
\hline
\end{tabular}


different studies have reported increase in loading efficiency by increasing carboxylic acid contents in polymer chains (Khan et al., 2013; Johansen et al., 1998). Concerning point " $\mathrm{b}$ ", by increasing cross-linking agent there is an increase in the number of links between two cross-links that leads to a decrease in porosity (see table III), leading to a decrease in loading efficiency. Desai et al. prepared chitosan microspheres by using three different cross-linkers and found a decrease in encapsulation when increasing cross-linker concentration from $1 \%$ to $2 \%$ (Desai, Park, 2005).

Effect of $\mathrm{pH}$ on drug release was investigated by obtaining dissolution profiles at various $\mathrm{pH}$ such as 1.2, 5.5 and 7.5. In all the samples, drug release increased with increasing $\mathrm{pH}$ of the medium.

In solutions of low $\mathrm{pH}$, carboxylic groups of AA remain unionised and hydrogen bonding of PVP and AA also remain intact, resulting in decreased swelling and drug release. On increasing $\mathrm{pH}$ value of the medium above the $\mathrm{pK}_{\mathrm{a}}$ value, i.e. 4.26 of AA, carboxyl groups dissociate to form carboxylate ions, which also result in the destruction of hydrogen bonds between PVP and AA. It also results in a decrease in the cross-linked density. Additionally, charge repulsion results in an increased swelling, which originates from a higher concentration of $\mathrm{COO}^{-}$groups. These effects ultimately lead to increased drug release (Jin et al., 2009).

In $\mathrm{pH}$-sensitive hydrogels, concentration of the carboxylic group containing the monomer plays a vital role: it can influence properties of hydrogels, for example drug loading, porosity and swelling. In our case, AA provides carboxylic groups. Figure 4 shows the effect of AA concentration on drug release at $\mathrm{pH} 1.2,5.5$ and 7.5 for $12 \mathrm{~h}$ at $37^{\circ} \mathrm{C}$. In these gels, drug release is directly proportional to AA content. We believe that AA content influences porosity (Table III) of gels, and thereby, dissolution media can easily enter the gel matrix to elute the entrapped drug. Secondly, it also increases initial drug loading. Thus the higher the drug contents, the higher will be the release.

Similar kinds of findings have been reported previously (Ranjha et al., 2011; Ranjha et al., 2010).

In the final part of the drug-release studies, we studied the effect of varying concentration of cross-linking agent while keeping the PVP/AA content constant. Figure 5 shows the effect of MBA concentration on drug release. It was observed that by increasing the MBA concentration, there was a decrease in drug release at all $\mathrm{pH}$ values due to a decrease in the mesh size of hydrogels and the presence of hydrogen bonding between PVP and AA, which retarded expansion of the network and chain relaxation. A number of authors have reported similar findings (Chen

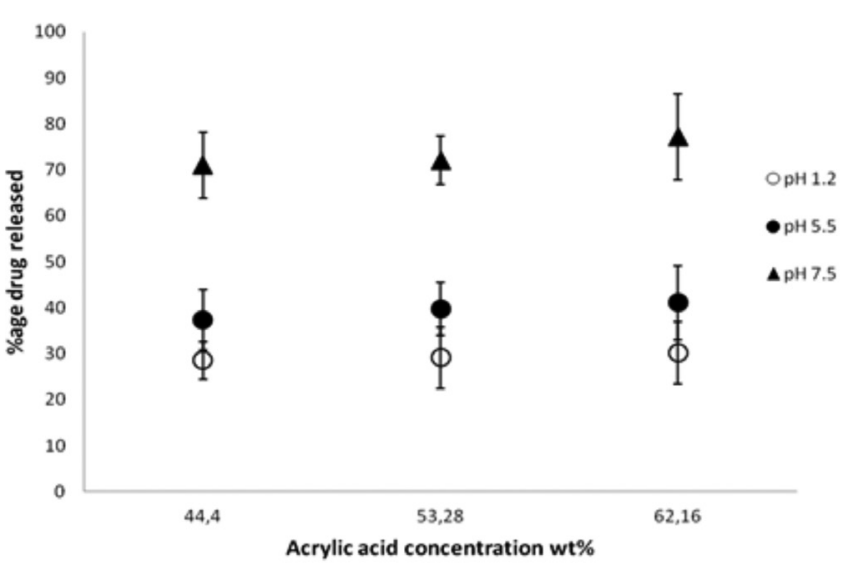

FIGURE 4 - Effect of acrylic acid concentration on tramadol $\mathrm{HCl}$ release after $12 \mathrm{~h}$ from PVP/AA copolymer with $0.3 \%$ MBA as cross-linking agent in solutions of $\mathrm{pH} 1.2$ (o), $5.5(\bullet)$ and $7.5(\mathbf{\Delta})$ at $37^{\circ} \mathrm{C}$.

et al., 2005; Li et al., 2006). Our results are also supported by network structure parameters including $\mathrm{N}$ and D (Table III): both the number of links between two cross-links (N) and the diffusion coefficient (D) is decreased by increasing the concentration of cross-linker.

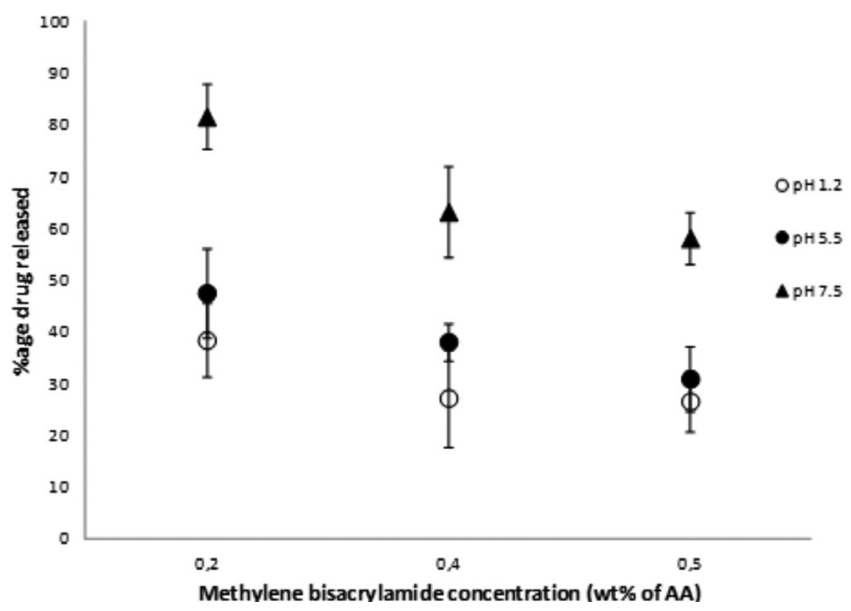

FIGURE 5 - Effect of methylene bisacrylamide concentration on tramadol $\mathrm{HCl}$ release after $12 \mathrm{~h}$ from PVP/AA copolymer, keeping polyvinyl pyrrolidone and acrylic acid concentration constant in solutions of pH $1.2(\mathrm{o}), 5.5(\bullet)$ and $7.5(\boldsymbol{\Delta})$ at $37^{\circ} \mathrm{C}$.

\section{Analysis of drug-release pattern}

In order to have a better understanding of the release mechanism, we used the Korsmeyer-Peppas equation to elucidate the possible transport mechanism. In general, this equation is used to analyse release of a drug where the mechanism is not well known or when more than one type of release phenomenon is involved. In gels, chain 
TABLE V - Effect of acrylic acid and MBA on the tramadol release mechanism of PVP/AA hydrogel at different $\mathrm{pH}$

\begin{tabular}{|c|c|c|c|c|c|}
\hline Sample code & $\begin{array}{c}\text { Acrylic acid content } \\
(\%)\end{array}$ & $\begin{array}{l}\text { MBA content } \\
(\mathrm{wt} \% \text { of AA) }\end{array}$ & $\mathrm{pH}$ & $\mathrm{R}^{2}$ & $\begin{array}{l}\text { Release exponent } \\
\text { (n) }\end{array}$ \\
\hline \multirow[t]{3}{*}{$\overline{A_{1}}$} & 44.40 & & 1.2 & 0.9878 & 0.8057 \\
\hline & & 0.30 & 5.5 & 0.9961 & 0.6684 \\
\hline & & & 7.5 & 0.9960 & 0.5810 \\
\hline \multirow[t]{3}{*}{$\mathrm{A}_{2}$} & 53.28 & & 1.2 & 0.9856 & 0.7967 \\
\hline & & 0.30 & 5.5 & 0.9902 & 0.7593 \\
\hline & & & 7.5 & 0.9935 & 0.7697 \\
\hline \multirow[t]{3}{*}{$\mathrm{A}_{3}$} & 62.16 & & 1.2 & 0.9903 & 0.8076 \\
\hline & & 0.30 & 5.5 & 0.9941 & 0.8080 \\
\hline & & & 7.5 & 0.9938 & 0.8289 \\
\hline \multirow[t]{3}{*}{$\mathrm{C}_{1}$} & & & 1.2 & 0.9955 & 0.7581 \\
\hline & & 0.20 & 5.5 & 0.9814 & 0.8811 \\
\hline & & & 7.5 & 0.9886 & 0.8002 \\
\hline \multirow[t]{3}{*}{$\mathrm{C}_{2}$} & & & 1.2 & 0.9895 & 0.7853 \\
\hline & & 0.40 & 5.5 & 0.9976 & 0.5272 \\
\hline & & & 7.5 & 0.9918 & 0.5676 \\
\hline \multirow[t]{3}{*}{$\mathrm{C}_{3}$} & & & 1.2 & 0.9729 & 0.7217 \\
\hline & & 0.50 & 5.5 & 0.9801 & 0.5133 \\
\hline & & & 7.5 & 0.9919 & 0.6401 \\
\hline
\end{tabular}

relaxation and relative rate of diffusion is responsible for three different modules of diffusion, presenting distinct values of the diffusional exponent (n). The " $n$ " values were calculated from the slope of $\ln \mathrm{M}_{\mathrm{t}} / \mathrm{M}_{\infty}$ versus $\ln (\mathrm{t})$ plot using linear regression analysis (Khan et al., 2013). All the formulations showed good linearity $\left(\mathrm{R}^{2} \geq 0.98\right)$ and " $n$ " values were between 0.5 and 1 (Table V) suggesting tramadol $\mathrm{HCl}$ release follows a non-Fickian diffusion mechanism. Thus diffusion and chain relaxation of the polymer is involved in release of the drug.

\section{CONCLUSIONS}

pH-Sensitive PVP/AA hydrogels were synthesised using MBA as cross-linker and tramadol $\mathrm{HCl}$ as a model hydrophilic drug. Grafting of AA to PVP not only improves mechanical properties of hydrogels but also make them $\mathrm{pH}$ sensitive. Swelling of these gels could be controlled by the optimum concentration of AA, PVP and MBA. Acrylic acid increases swelling while polyvinyl pyrrolidone and cross-linker decrease it. These effects are well explained by structural parameters. Tramadol $\mathrm{HCl}$ release from these gels was directly proportional to drug loading and acrylic acid content while inversely proportional to cross-linker concentration. The drug-release pattern could be predicted from structural parameter of gels. We believe that use of these parameters could provide useful information on hydrogel behaviour under different conditions and could be used to predict the behaviour of drugs entrapped in them. This can help in saving time and costs incurred on drug-release experiments. Finally, drug release mechanism was elucidated by the Korsmeyer-Peppas model and found to be non-Fickian. Thus, $\mathrm{pH}$-sensitive PVP/AA hydrogels can be modified by varying composition and degree of cross-linking for optimum colon-targeted drug delivery.

\section{REFERENCES}

ANSETH, K.S.; BOWMAN, C.N.; BRANNON-PEPPAS, L. Mechanical properties of hydrogels and their experimental determination. Biomaterials, v.17, n.17, p.1647-1657, 1996.

BAJPAI, S.K., SEEMA, D. In vitro dissolution studies for release of vitamin B12 from poly(N-vinyl-2-pyrrolidoneco-acrylic acid) hydrogels. React. Funct. Polym., v 62, n.1, p.93-104, 2005. 
BENAMER, S.; MAHLOUS, M.; BOUKRIF, A.; MANSOURI, B.; YOUCEF, S.L. Synthesis and characterisation of hydrogels based on poly(vinyl pyrrolidone). Nucl. Instrum. Methods Phys., Sect B, v.248, n.2, p.284-290, 2006.

CHEN, K.S.; KU, Y.A.; LIN, H.R.; YAN, T.R.; SHEU, D.C.; CHEN, T.M.; LIN, F.H. Preparation and characterization of $\mathrm{pH}$ sensitive poly(N-vinyl-2-pyrrolidone/itaconic acid) copolymer hydrogels. Mater. Chem. Phys., v.91, n.2-3, p.484-489, 2005.

CRANK, J. The mathematics of diffusion. 2. ed. Oxford: Oxford University Press, 1979. 414 p.

DESAI, K.G.H.; PARK, H.J. Preparation of cross-linked chitosan microspheres by spray drying: effect of crosslinking agent on the properties of spray dried microspheres. J. Microencapsul., v.22, n.4, p.377-395, 2005.

DEVINE, D.M.; HIGGINBOTHAM, C.L. Synthesis and characterisation of chemically crosslinked N-vinyl pyrrolidinone (NVP) based hydrogels. Eur. Polym. J., v.41, n.6, p.1272-1279, 2005.

EL-HAG, A.A.; SHAWKY, H.A.; ABD EL REHIM, H.A.; HEGAZY, E.A. Synthesis and characterization of PVP/AAc copolymer hydrogel and its applications in the removal of heavy metals from aqueous solution. Eur. Polym. J., v.39, n.12, p.2337-2344, 2003.

ENTEZAMI, A.A.; MASSOUMI, B. Artificial muscles, biosensors and drug delivery systems based on conducting polymers: a review. Iranian Polym. J., v.15, n.1, p.13-30, 2006.

FLORY, P.J. Principles of polymer chemistry. New York: Cornell University Press, 1953. 672 p.

GAHARWAR, A.K.; RIVERA, C.P.; WU, C.J.; SCHMIDT, $\mathrm{G}$. Transparent, elastomeric and tough hydrogels from poly(ethylene glycol) and silicate nanoparticles. Acta Biomater., v.7, n.12, p.4139-4148, 2011.

GANJI, F.; FARAHANI, E.V. Hydrogels in controlled drug delivery systems. Iranian Polym. J., v.18, n.1, p.63-88, 2009.

HAFEEZ, H.S.; ALI, A.E.; ABDEL-MOTTALEB, M.S.A. Photocatalytic efficiency of titinum dioxide immobilized on PVP/AAc hydrogel membranes: a comparative study for safe disposal of waste water of Remazol Red RB-133 textile dye. Int. J. Photoenergy, v.7, n.4, p.181-185, 2005.
HUSSAIN, A.; KHALID, S.H; QADIR, M.I.; MASSUD, A.; ALI, M.; KHAN, I.U.; SALEEM, M.; IQBAL, M.; ASGHAR, S.; GUL, H. Water uptake and drug release behaviour of methyl methacrylateco-itaconic acid [P(MMA/ IA)] hydrogels cross-linked with methylene bis-acrylamide. J. Drug Del. Sci. Tech., v.21, n.3, p.249-255 2011.

JIN, L.; LU, P.; YOU, H.; CHEN, Q.; DONG, J. Vitamin B12 diffusion and binding in crosslinked poly(acrylic acid)s and poly(acrylic acid-co-N-vinyl pyrrolidinone)s. Int. J. Pharm., v.371, n.1-2, p.82-88, 2009.

JIN, S.; LIU, M.; ZHANG, F.; CHEN, S.; NIU, A. Synthesis and characterization of $\mathrm{pH}$-sensitivity semi-IPN hydrogel based on hydrogen bond between poly(N-vinylpyrrolidone) and poly(acrylic acid). Polymer, v.47, n.5, p.1526-1532, 2006.

JOHANSEN, P.; MEN, Y.; AUDRAN, R.; CORRADIN, G.; MERKLE, H.; GANDER, B. Improving stability and release kinetics of microencapsulated tetanus toxoid by co-encapsulation of additives. Pharm. Res., v.15, n.7, p.1103-1110, 1998.

KADŁUBOWSKI, S.; HENKE, A.; ULAŃSKI, P.; ROSIAK, J.M.; BROMBERG, L.; HATTON, T.A. Hydrogels of polyvinylpyrrolidone (PVP) and poly(acrylic acid) (PAA) synthesized by photoinduced crosslinking of homopolymers. Polymer, v.48, n.17, p.4974-4981, 2007.

KATIME, I.; VALDERRUTEN, N.; QUINTANA, J.R. Controlled release of aminophylline from poly (N-isopropylacrylamide-co-itaconic acid) hydrogels. Polym. Int., v.50, n.8, p.869-879, 2001.

KHAN, I.U.; SERRA, C.A.; ANTON, N.; VANDAMME, T. Continuous-flow encapsulation of ketoprofen in copolymer microbeads via co-axial microfluidic device: Influence of operating and material parameters on drug carrier properties. Int. J. Pharm., v.441, n.1-2, p.809-817, 2013.

KOÇ, M.L.; ÖZDEMIR, Ü.; İMREN, D. Prediction of the $\mathrm{pH}$ and the temperature-dependent swelling behavior of -alginate hydrogels by artificial neural networks. Chem. Eng. Sci., v.63, n.11, p.2913-2919, 2008.

LI, X.; WU, W.; WANG, J.; DUAN, Y. The swelling behavior and network parameters of guar gum/poly(acrylic acid) semi-interpenetrating polymer network hydrogels. Carbohydr. Polym., v.66, n.4, p.473-479, 2006. 
LIN, C.C.; METTERS, A.T. Hydrogels in controlled release formulations: network design and mathematical modeling. Adv. Drug Deliv. Rev., v.58, n.12-13, p.1379-1408, 2006.

LIN, W.J.; LU, C.H. Characterization and permeation of microporous poly( $\varepsilon$-caprolactone) films. J. Membr. Sci., v.198, n.1, p.109-118, 2002.

MISHRA, R.K.; DATT, M.; BANTHIA, A.K. Synthesis and characterization of Pectin/PVP hydrogel membranes for drug delivery system. AAPS Pharm. Sci. Tech., v.9, n.2, p.395-403, 2008.

PEPPAS, N.A.; BURES, P.; LEOBANDUNG, W.; ICHIKAWA, H. Hydrogels in pharmaceutical formulations. Eur. J. Pharm. Biopharm., v.50, n.1, p.27-46, 2000.

PEPPAS, N.A.; HILT, J.Z.; KHADEMHOSSEINI, A.; LANGER, R. Hydrogels in biology and medicine: from molecular principles to bionanotechnology. Adv. Mater., v.18, n.11, p.1345-1360, 2006.

PEPPAS, N.A. (Ed.). Hydrogels in medicine and pharmacy: fundamentals. Boca Raton: CRC Press, 1986. v.1, 180 p.

RANJHA, N.M.; AYUB, G.; NASEEM, S.; MUHAMMAD, A. Preparation and characterization of hybrid $\mathrm{pH}$-sensitive hydrogels of chitosan-co-acrylic acid for controlled release of verapamil. J. Mater. Sci-Mater. M., v.21, n.10, p.28052816, 2010.

RANJHA, N.M.; KHAN, I.U.; NASEEM, S. Encapsulation and characterization of flurbiprofen loaded poly( $\epsilon-$ caprolactone)-poly(vinylpyrrolidone) blend micropheres by solvent evaporation method. J. Sol-Gel Sci. Technol, v.50, n.3, p.281-289, 2009.

RANJHA, N.M.; MUDASSIR, J.; SHEIKH, Z.Z. Synthesis and characterization of $\mathrm{pH}$-sensitive pectin/acrylic acid hydrogels for verapamil release study. Iranian Polym. J., v.20, n.2, p.147-159, 2011.
RAY, D.; SAHOO, P.K; MOHANTA, G.P. Designing of super porous cross-linked hydrogels containing acrylic-based polymer network. Asian J. Pharm., v.2, n.2, p.123-127, 2008.

ŞAHINER, N.; MALC, S.; ÖMUR, C.; ÖMER, K.; BEKIR, S. Radiation synthesis and characterization of new hydrogels based on acrylamide copolymers cross-linked with 1-allyl2-thiourea. Radiat. Phys. Chem., v.74, n.2, p.76-85, 2005.

SATISH, C.S.; SATISH, K.P.; SHIVAKUMAR, H.G. Hydrogels as controlled drug delivery systems: synthesis, crosslinking, water and drug transport mechanism. Indian J. Pharm. Sci., v.68, n.2, p.133-140, 2001.

SEN, M.; AVCI, E.N. Radiation synthesis of poly(N-vinyl2-pyrrolidone)-k-carrageenan hydrogels and their use in wound dressing applications. I. Preliminary laboratory tests. J. Biomed. Mater Res. A., v.74A, n.2, p.187-196, 2005.

SZEPES, A.; MAKAI, Z.; BLÜMER, C.; MÄDER, K.; JR, P.K.; SZABÓ-RÉVÉSZ, P. Characterization and drug delivery behaviour of starch-based hydrogels prepared via isostatic ultrahigh pressure. Carbohydr. Polym., v.72, n.4, p.571-578, 2008.

YIN, L.; FEI, L.; CUI, F.; TANG, C.; YIN, C. Superporous hydrogels containing poly(acrylic acid-co-acrylamide)/Ocarboxymethyl chitosan interpenetrating polymer networks. Biomaterials, v.28, n.6, p.1258-1266, 2007.

ZHAO, L.; XU, L.; MISTOMO, H.; YOSHII, F. Synthesis of $\mathrm{pH}$-sensitive PVP/CM-chitosan hydrogels with improved surface property by irradiation. Carbohydr. Polym., v.64, n.3, p.473-480, 2006.

Received for publication on $27^{\text {th }}$ August 2013 Accepted for publication on $09^{\text {th }}$ January 2014 